\title{
NHIỄM CANDIDA DA VÀ NIÊM MẠC MẠN TÍNH
}

\author{
Nguyễn Minh Tuấn ${ }^{1,2}$ \\ 1. Bệnh viện Nhi Đồng 1, TP.HCM \\ 2. Khoa Y, Đại học Quốc gia TP.HCM
}

\section{1. ĐĂT VẤN ĐÊ}

Candida da và niêm mạc mạn tính (Chronic mucocutaneous candidiasis: $\mathrm{CMCC}$ ) là một nhóm hội chứng không đồng nhất với các đặc điểm chung của nhiễm nấm Candida mạn tính không xâm lấn ở da, móng và niêm mạc thường kháng điều trị tại chỗ và không có nhiễm nấm xâm lấn. Các dạng cổ điển có các biểu hiện liên quan tự miễn (thường gặp nhất là bệnh nội tiết), và bệnh nhân có thể bị nhiễm vi sinh vật khác. Các dạng nhẹ hơn có nhiễm nấm Candida miệng có hoặc không kèm theo nhiễm trùng da do tụ cầu. CMCC là do khiếm khuyết di truyền trong hệ thống miễn dịch[1].

Candida da niêm mạc mạn tính là một nhóm bệnh do suy giảm miễn dịch tiên phát có liên quan đến khiếm khuyết tế bào $T$. Di truyền có thể.

- Gen trội thường: Tham gia vào một đột biến trong bộ chuyển đổi tín hiệu và hoạt hóa của gen phiên mã 1 (STAT1).

- Gen lặn thường: Tham gia vào một đột biến trong gen điều hòa tự miễn (AIRE).

Ở dạng lặn (bệnh đa tuyến nội tiết tự miễnnấm Candida-loạn dướng ngoại bì [Autoimmune polyendocrinopathy-candidiasis-ectodermal dystrophy (APECED)] biểu hiện tự miễn dịch thường phát triển; chúng bao gồm rối loạn nội tiết (ví dụ như suy tuyến giáp, suy thượng thận, suy nhược thần kinh, rối loạn tuyến giáp, đái tháo đường), chứng rụng tóc, thiếu máu ác tính và viêm gan. Các đột biến cũng có thể xảy ra ở các gen mã hoá các protein khác nhau tham gia vào phản ứng miễn dịch bẩm sinh đối với nấm, đặc biệt là:

- PTPN22 (còn được gọi là LYP, hay tyrosine phosphatase của lympho bào) liên quan đến tín hiệu thụ thể tế bào T).

- Dectin-1 (một thụ thể nhận biết của hệ miễn dịch tự nhiễn cần thiết cho việc kiểm soát nhiễm nấm).

- CARD9 (một phân tử thích ứng quan trọng trong sản xuất IL-17 để bảo vệ chống lại sự xâm nhập của nấm).

Bệnh nấm Candida thường tái phát hoặc dai dẳng, thường bắt đầu từ khi còn nhỏ nhưng đôi khi trong giai đoạn đầu trưởng thành. Tuổi thọ không bị ảnh hưởng. Một số bệnh nhân cũng có suy giảm miễn dịch dịch thể (thiếu hụt kháng thể), đặc trưng bởi đáp ứng kháng thể bất thường đối với kháng nguyên polysaccharide mặc dù mức độ globulin miễn dịch bình thường.

2. CÁC DANG CỔ ĐIỂN CỦA CMCC LIÊN QUAN BỆNH TỰ MIỄN

Nhận bài: 20-9-2020; Chấp nhân: 8-10-2020 
Các dạng cổ điển của CMCC là do các biến thể gây bệnh trong gen điều hòa tự miễn dịch (AIRE) hoặc bộ chuyển đổi tín hiệu và hoạt hóa của gen phiên mã 1 [signal transducer and activator of transcription 1 gene (STAT1)].

CMCC cổ điển có liên quan đến một loạt các đặc điểm lâm sàng:

- Các biểu hiện tự miễn khác ngoài bệnh nội tiết, bao gồm thiếu máu tan máu tự miễn, giảm tiểu cầu miễn dịch, giảm bạch cầu tự miễn và viêm khớp dạng thấp.

- Suy tủy với nhiều mức độ khác nhau kèm theo thiếu máu bất sản.

- Các bệnh ung thư, chủ yếu liên quan đến miệng và thực quản, cũng như u tuyến ức lành tính và ác tính.

- Nhiều bất thường trong hệ thống miễn dịch bao gồm tăng sinh tế bào $T$ in vitro bất thường đối với kháng nguyên Candida, thiếu hụt miễn dịch dịch thể và tăng tính nhạy cảm với các bệnh nhiễm trùng do vi khuẩn và virus.

Thiếu hụt chất điều hòa tự miễn dịch: Thiếu hụt chất điều hòa tự miễn dịch (AIRE) chiếm phần lớn các trường hợp $\mathrm{CMCC}$ ở các dân số khác nhau, chẳng hạn như người Phần Lan và Sardinia, nhứng chỉ có 20 đến $40 \%$ các trường hợp ở các quần thể khác [2]. Các khảo sát phát hiện với tần suất 1: 9000 ở người Do Thái, 1: 14.500 ở người Sardinia, và 1: 25.000 ở người Phần Lan. Gen AIRE nằm trên nhiễm sắc thể $21 q 22.3$ [3], di truyền theo kiểu lặn trên NST thường. Hơn 50 đột biến đã được mô tả cho đến nay, với đột biến phổ biến nhất là R257X trong dân số Phần Lan.

Bệnh nhân bị nhiễm nấm Candida mạn tính cũng như bệnh đa tuyến nội tiết tự miễn, thường gặp nhất là suy tuyến cận giáp và suy tuyến thượng thận, và chứng loạn dưỡng da, do đó có tên gọi cho chứng rối loạn này: Bệnh đa tuyến nội tiết tự miễn-nấm Candida-loạn dưỡng ngoại bì (APECED). Rối loạn này còn được gọi là hội chứng đa tuyến nội tiết tự miễn loại I (APS1).

Các đặc điểm lâm sàng của thiếu AIRE/ APECED - Thiếu AIRE/bệnh đa nội mạc tự miễn dịch-bệnh nấm Candida-loạn dưỡng ngoại bì (APECED) được biết đến với sự khác biệt nhiều trong biểu hiện lâm sàng và diễn biến bệnh, ngay cả trong số các thành viên gia đình bị ảnh hưởng mang dị tật di truyền giống hệt nhau [2]. Sự không đồng nhất về mặt lâm sàng này có thể dẫn đến sự chậm trễ đáng kể trong chẩn đoán [4]. Biểu hiện đầu tiên của bệnh có thể bắt đầu ở độ tuổi từ hai tháng đến> 18 tuổi [5].

Tam chứng cổ điển là nhiễm nấm Candida da niêm mạc, suy tuyến cận giáp và suy thượng thận [5]:

- Nhiễm nấm Candida mạn tính hoặc đôi khi tái phát ở khoang miệng, móng tay và da, và ít thường xuyên hơn là thực quản, âm đạo và đường tiêu hóa, là biểu hiện xuất hiện ở $60 \%$ bệnh nhân và ảnh hưởng đến tất cả bệnh nhân khi đạt 40 tuổi. Các tổn thương trên da thường gồ lên và đôi khi gây biến dạng. Tương tự, các giường móng bị ảnh hưởng dẫn đến móng bị dị dạng về cấu trúc. Những thay đổi này có thể là do sự kết hợp của nhiễm trùng và phản ứng viêm quá mức (tự miễn dịch). Candida albicans là tác nhân phổ biến nhất gây nhiễm trùng. 


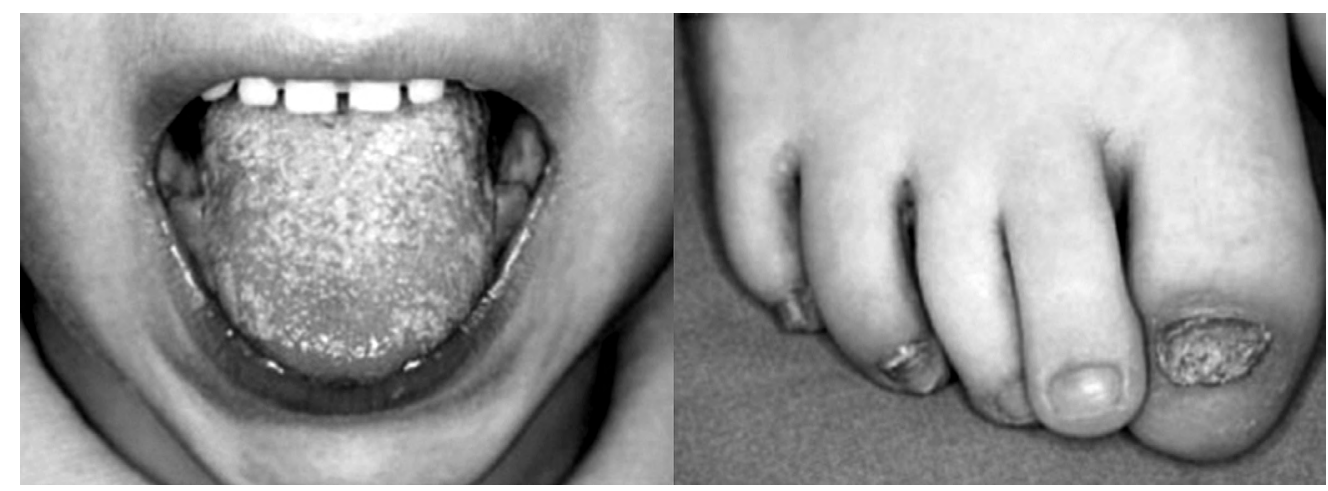

a

b

Hình 1. Nấm miệng (a) và nấm móng (b) ở bệnh nhân nhiễm nấm Candida da niêm mạc mạn tính

- Suy tuyến cận giáp là bất thường nội tiết phổ biến nhất trong bệnh này và là đặc điểm phổ biến thứ hai trong bệnh thiếu AIRE, xảy ra khi xuất hiện ở khoảng $30 \%$ bệnh nhân. Hơn $80 \%$ bệnh nhân cuối cùng bị biến chứng này. Suy tuyến cận giáp xuất hiện sớm hơn và thường gặp ở nữ hơn nam. Kết quả là hạ calci huyết và hạ magne huyết đôi khi khó kiểm soát và có thể dẫn đến co giật.

- Suy tuyến thượng thận là đặc điểm phổ biến thứ ba trong bệnh. Nó chỉ xảy ra với khoảng $5 \%$ khi xuất hiện nhưng xảy ra ở hơn $60 \%$ các trường hợp ở độ tuổi 15 tuổi.

\section{Các biểu hiện khác ít phổ biến hơn:}

- Các bệnh nội tiết khác bao gồm đái tháo đường týp 1, suy giáp, thiếu hụt hormone tăng trưởng, bệnh Addison, suy buồng trứng (có thể cùng tồn tại với suy thượng thận) và suy sinh dục nam.

- Các biểu hiện tự miễn dịch khác bao gồm bệnh bạch biến và rụng tóc từng mảng, ảnh hưởng đến hơn $30 \%$ bệnh nhân sau 20 tuổi và có thể tiến triển thành chứng hói đầu. Thiếu máu ác tính ảnh hưởng đến hơn $20 \%$ bệnh nhân sau 30 tuổi. Viêm gan hiếm gặp.

- Các biến chứng được cho là do nhiễm
Candida mạn tính bao gồm viêm kết mạc, có thể dẫn đến mù lòa, hẹp thực quản và ung thư biểu mô tế bào vảy của miệng và thực quản.

- Có thể xảy ra thiếu hụt kháng thể đối với kháng nguyên polysaccharide.

- Các biểu hiện đường tiêu hóa và miệng khác bao gồm bất thường men răng, tiêu chảy mạn tính và táo bón [5].

- Các đặc điểm khác của mắt được báo cáo bao gồm đục thủy tinh thể vỏ và viêm mống mắt thể mi mạn tính [6].

- Bệnh phổi, viêm thận kẽ và bệnh não cũng có thể xảy ra [7].

Thiếu AIRE cũng có thể xuất hiện với các đặc điểm bất thường. Trẻ nhỏ, ngay cả trong năm đầu đời, có thể bị sốt và phát ban định kỳ, khô mắt, suy tuyến tụy ngoại tiết, hoặc liên quan đến thận, bao gồm hạ kali máu, tăng huyết áp, hoặc viêm thận mô kẽ.

40 đến $80 \%$ bệnh nhân ở Bắc Mỹ có các đặc điểm lâm sàng không phổ biến ở các nhóm người châu Âu, bao gồm mày đay, viêm ruột, viêm phổi và hội chứng giống Sjögren [8].

Rối loạn chức năng bộ chuyển đổi tín hiệu và hoạt hóa của gen phiên mã (STAT1). 
Các biểu hiện lâm sàng ở bệnh nhân rối loạn chức năng STAT1 rất rộng nhưng thường gặp nhất là nấm miệng cũng như nấm da và nhiễm trùng móng. Các bệnh nhiễm trùng do vi sinh vật bao gồm viêm xoang, viêm phổi và viêm nang lông cũng rất phổ biến [9]. Nhiễm virus với virus Herpes, virus Papillomavirus và virus Human polyomavirus 2 ít phổ biến hơn. Tuy nhiên, những bệnh nhiễm virus này có thể đe dọa tính mạng ở một số ít bệnh nhân có tiến triển dần thành suy giảm miễn dịch kết hợp nặng và cũng có thể khiến họ mắc các bệnh nhiễm nấm xâm lấn như Coccidioidomycosis, Histoplasmosis và Mucormycosis.

Có tới một nửa số bệnh nhân bị rối loạn chức năng STAT1 bị suy giáp, bệnh giống bệnh viêm ruột (inflammatory bowel disease (IBD)-like disease), hoặc giảm tế bào máu do tự miễn [60]. Hiếm khi một số bệnh nhân bị đột quỵ nặng và tái diễn do viêm mạch máu não và nhiều túi phình mạch, chủ yếu ở các mạch máu kích thước trung bình (bệnh giống Moyamoya).

Bệnh nhân bị tổn thương da nghiêm trọng có nguy cơ phát triển ung thư da cao hơn. Những bệnh nhân khác bị suy giảm khả năng miễn dịch ngày càng tăng có nguy cơ phát triển bệnh phổi mạn tính hoặc nhiễm virus hoặc nấm.

Các đột biến STAT1 khác gây mất biểu hiện và mất chức năng tạo ra các kiểu hình khác nhau, chẳng hạn như nhạy cảm với nhiễm trùng vi khuẩn và virus hoặc suy giảm miễn dịch kết hợp.

\section{THIẾU HỤT MIỄN DICH THEO CON ĐƯờNG} IL-17

Các đột biến trong gen IL-17RA, IL-17RC, IL-17F và $A C T 1$ đều có liên quan đến các mức độ khác nhau của bệnh nấm Candida da niêm mạc. Kiểu hình của chúng không chỉ giới hạn ở các trường hợp nhiễm nấm Candida nông, và thường thì đặc điểm nổi bật hơn của chúng là nhiễm trùng nặng với Staphylococcus aureus hoặc Mycobacteria[10].

\section{CÁC KHIẾM KHUYẾT DI TRUYỀN KHÁC}

Các khiếm khuyết di truyền khác có liên quan đến số lượng trường hợp nhỏ hơn nhiều và thường được tìm thấy trong một gia đình. Những khiếm khuyết di truyền này đều là những yếu tố làm thay đổi bệnh. Trong một số trường hợp, di truyền có thể liên quan đến tác động của nhiều gen, như được thấy ở một số bệnh nhân bị đột biến lymphoid phosphatase (Lyp) và Dectin-1.

\section{CHẨN ĐOÁN}

Chẩn đoán $\mathrm{CMCC}$ chủ yếu dựa trên các đặc điểm lâm sàng bao gồm nhiễm nấm Candida mạn tính, không xâm lấn ở da và niêm mạc liên quan đến các biểu hiện tự miễn dịch, thường gặp nhất là bệnh nội tiết. Hầu hết bệnh nhân được chẩn đoán trong thời kỳ trẻ em, nhưng một số không được xác định cho đến khi trưởng thành. Nếu nghi ngờ có khiếm khuyết STAT1, chức năng STAT1 nên được kiểm tra trong các tế bào lympho máu ngoại vi mới lấy. Chẩn đoán được xác nhận bằng cách xác định một đột biến gây bệnh. Nếu nghi ngờ khiếm khuyết liên quan đến con đường interleukin (IL) 17 nhưng ý nghĩa của các bất thường di truyền không rõ ràng, thì việc đánh giá chức năng cytokine và đáp ứng của thụ thể cytokine có thể có giá trị về mặt lâm sàng. (Xem “Các dạng CMCC cổ điển có liên quan đến 
tự miễn dịch" ở trên và "Thiếu hụt miễn dịch theo con đường IL-17" ở trên và "Các khiếm khuyết di truyền khác" ở trên).

\section{XÉT NGHIỆM ĐÁNH GIÁ}

Tất cả bệnh nhân nhiễm nấm Candida mạn tính nên được đánh giá xem có nghi ngờ suy giảm miễn dịch nguyên phát hay không[1]. Điều này nên bao gồm công thức máu; nồng độ immunoglobulin bao gồm cả immunoglobulin $\mathrm{E}$ ( $\lg \mathrm{E})$; lympho $\mathrm{T}, \mathrm{B}$ và tế bào tiêu diệt tự nhiên (NK); và chức năng tế bào T. Xét nghiệm duy nhất để chẩn đoán $\mathrm{CMCC}$ là phân tích di truyền của các gen liên quan. Tuy nhiên, các tự kháng thể chống lại interferon (IFN) alpha và IFN-omega luôn cao ở những bệnh nhân có đột biến AIRE. Việc đo lường các tự kháng thể chống lại IFN-omega cũng như interleukin (IL) 17A, IL-17F và IL-22 có thể giúp phân biệt CMCC do nguyên nhân di truyền với các bệnh giống bệnh tự miễn.

Các xét nghiệm khác ít chắc chắn hơn nhưng có thể hỗ trợ chẩn đoán, bao gồm các xét nghiệm chuẩn để đánh giá các rối loạn nội tiết, như suy tuyến cận giáp và suy tuyến thượng thận có liên quan đến CMCC. Công thức máu có thể cho thấy thiếu máu, hoặc do thiếu sắt (hồng cầu nhỏ, nhược sắc) hoặc do thiếu vitamin B12 (hồng cầu to). Cả hai đều có thể do kém hấp thu và teo tế bào thành.

Đánh giá hệ miễn dịch có thể xác định tình trạng không có khả năng đáp ứng chọn lọc trong in vitro (tăng sinh tế bào $T$ ) hoặc in vivo (phản ứng quá mẫn kiểu chậm ở da) đối với Candida, đặc biệt ở những bệnh nhân thiếu AIRE. Ở những bệnh nhân khác, có thể ghi nhận giảm tế bào lympho và các bất thường trong phản ứng kháng nguyên và phân bào in vitro. Trong một nhóm thuần tập, 20 phần trăm bệnh nhân thiếu CMCC điều hòa không tự miễn dịch (AIRE) đã giảm số lượng và/ hoặc chức năng của các tế bào T lưu hành. Bệnh nhân có đột biến STAT1 trong vùng liên kết DNA có thể bị suy giảm dần các tế bào $T$, $B$ và NK cũng như suy giảm chức năng của tế bào $\mathrm{T}$.

Miễn dịch dịch thể cũng có thể bị ảnh hưởng ở những bệnh nhân mắc CMCC không do thiếu AIRE và bao gồm giảm lgG2 và lgG4, giảm gammaglobulin và đáp ứng không đầy đủ với việc tiêm chủng kháng nguyên polysaccharide (ví dụ: vaccin phế cầu không liên hợp).

Kháng thể Candida huyết thanh không có giá trị trong chẩn đoán $\mathrm{CMCC}$, cũng như xét nghiệm lgE trên da hoặc huyết thanh để tìm Candida.

\section{CHẨN ĐOÁN KHÁC BIẸT}

Bệnh nấm Candida có thể gặp ở nhiều dạng suy giảm miễn dịch tiên phát. Thông thường, sự thiếu hụt tế bào $T$ tiên phát hoặc thứ cấp nặng dẫn đến tính nhạy cảm với Candida. Bệnh nhân bị suy giảm miễn dịch kết hợp nặng (SCID) và suy giảm miễn dịch mắc phải hầu như luôn luôn có biểu hiện nấm miệng và/ hoặc nhiễm nấm Candida ở da khác. Tuy nhiên, không giống như bệnh nhân $\mathrm{CMCC}$, nhiễm nấm Candida trong những rối loạn này có thể trở nên xâm lấn với sự lây lan toàn thân.

Bệnh tự miễn có thể giống các nguyên nhân di truyền của CMCC. Các tự kháng thể chống lại IL-17A, IL-17F và IL-22 do tế bào Th17 tạo ra đã được xác định ở bệnh nhân u tuyến ức mắc CMCC.

Nhiễm nấm Candida mạn tính cũng gặp ở bệnh nhân tiểu đường, nhiễm virus gây suy 
giảm miễn dịch ở người (HIV), hoặc ở bệnh nhân được điều trị bằng glucocorticoid toàn thân hoặc hít hoặc các đợt kháng sinh kéo dài.

\section{8. ĐIỀU TR!}

Điều trị bao gồm liệu pháp kháng nấm và điều trị các bất thường liên quan đến nội tiết và tự miễn dịch[1].

Bệnh nấm Candida thường khỏi khi điều trị với một thuốc kháng nấm của họ azole. Fluconazole là phương pháp điều trị ưu tiên, có hoạt tính tốt chống lại C. albicans, dễ sử dụng, ít tác dụng phụ và tương đối rẻ. Có thể tăng liều nếu có vấn đề gia tăng sự đề kháng, nhưng cuối cùng sẽ cần phải sử dụng một tác nhân azole khác. Có thể thử itraconazole, voriconazole hoặc posaconazole, theo thứ tự. Chức năng gan nên được theo dõi cẩn thận trong khi bệnh nhân đang điều trị toàn thân với các thuốc này. Amphotericin đã được sử dụng thành công trong những trường hợp nặng.

Các bất thường về nội tiết nên được điều trị bằng liệu pháp thay thế, khi có thể. Trong trường hợp suy tuyến cận giáp, cần theo dõi cẩn thận nồng độ calci, và cho uống bổ sung calci. Thường xuyên phải cung cấp magne để tránh co giật do hạ magne máu [5].

Thiếu hụt kháng thể, nếu nghiêm trọng, nên được điều trị bằng thay thế globulin miễn dịch.

Điều trị các bệnh tự miễn nếu có sau khi hội chẩn từng chuyên khoa có liên quan.

Kinh nghiệm trong việc kiểm soát các biểu hiện tự miễn dịch nặng trong $\mathrm{CMCC}$ chỉ giới hạn trong các báo cáo trường hợp đơn lẻ đề xuất các phương pháp điều trị hiệu quả.
Ghép tế bào gốc tạo máu hiếm khi thành công và có thể được coi là phương pháp điều trị cuối cùng trong những trường hợp nặng.

\section{TÀI LIỆU THAM KHẢO}

\section{Kirkpatrick $\mathrm{CH}$. Chronic mucocutaneous} candidiasis. The Pediatric infectious disease journal 2001; 20(2): 197-206.

2. Ahonen P, Myllarniemi S, Sipila I, Perheentupa J. Clinical variation of autoimmune polyendocrinopathy-candidiasis-ectodermal dystrophy (APECED) in a series of 68 patients. The New England journal of medicine 1990; 322(26): 1829-36.

3. Finnish-German AC. An autoimmune disease, APECED, caused by mutations in a novel gene featuring two PHD-type zinc-finger domains. Nature genetics 1997; 17(4): 399-403.

4. Mazza C, Buzi F, Ortolani F, et al. Clinical heterogeneity and diagnostic delay of autoimmune polyendocrinopathy - candidiasis - ectodermal dystrophy syndrome. Clinical immunology 2011; 139(1): 6-11.

5. Perheentupa J. Autoimmune polyendocrinopathy - candidiasis-ectodermal dystrophy. The Journal of clinical endocrinology and metabolism 2006; 91(8): 2843-50.

6. Merenmies L, Tarkkanen A. Chronic bilateral keratitis in autoimmune polyendocrinopathy candidiadis - ectodermal dystrophy (APECED). A long-term follow-up and visual prognosis. Acta ophthalmologica Scandinavica 2000; 78(5): 532-5.

7. Capalbo D, Improda N, Esposito A, et al. Autoimmune polyendocrinopathy - candidiasis - ectodermal dystrophy from the pediatric perspective. Journal of endocrinological investigation 2013; 36(10): 903-12. 
8. Ferre EM, Rose SR, Rosenzweig SD, et mucocutaneous candidiasis disease: presenting al. Redefined clinical features and diagnostic as treatment-resistant candidiasis and chronic criteria in autoimmune polyendocrinopathy - lung disease. Clinical immunology 2016; 164: 1-9. candidiasis-ectodermal dystrophy. JCl insight 2016; 1(13).

10. Puel A, Cypowyj S, Bustamante J, et al.

9. Dotta L, Scomodon O, Padoan R, et al. with inborn errors of interleukin-17 immunity. Clinical heterogeneity of dominant chronic Science (New York, NY) 2011; 332(6025): 65-8. 